\title{
Deadly Incidents in Bangladeshi Apparel Industry and Illustrating the Causes and Effects of These Incidents
}

\author{
Md. Morshadul Hasan ${ }^{1}$, Appel Mahmud ${ }^{1}$, Md. Samiul Islam² \\ ${ }^{1}$ Department of Accounting and Information Systems, Begum Rokeya University, Rangpur, Bangladesh \\ ${ }^{2}$ Department of Finance, Jagannath University, Dhaka, Bangladesh
}

\section{Email address:}

arif.morshad@gmail.com (Md. M. Hasan),mahmudappel@yahoo.com (A. Mahmud), sunny.melange@gmail.com (Md. S. Islam)

\section{To cite this article:}

Md. Morshadul Hasan, Appel Mahmud, Md. Samiul Islam. Deadly Incidents in Bangladeshi Apparel Industry and Illustrating the Causes and Effects of These Incidents. Journal of Finance and Accounting. Vol. 5, No. 5, 2017, pp. 193-199. doi: 10.11648/j.jfa.20170505.13

Received: August 27, 2017; Accepted: August 27, 2017; Published: October 28, 2017

\begin{abstract}
The purposes of this paper are to explore the major deadly incidents of the apparel industry in Bangladesh and to illustrate the causes for these deadly incidents with the effect of these incidents. Different types of deadly incidents of the recent decade have made Bangladeshi apparel industry questionable. This paper will explore the causes of the different incidents and will show the precautionary measure of these problems of apparel industry which affected their sustainability and profitability.
\end{abstract}

Keywords: Major Hazard, Readymade Garments Industry, Death in Building Collapse, Building Collapse, Fire Hazards, RMG Hazards in Bangladesh, Rana Plaza, Tazreen Fashions, Apparel industry of Bangladesh

\section{Introduction}

Bangladesh is a country with poverty and overpopulation. It can utilize its overcrowding as human resource to overcome the poverty by itself. Ready-made garments sector is one of the most acceptable areas where the overpopulation can be utilized. It can be characterized by focusing some essential factors such as low material cost, low workforce cost, fast production with a lot of cheap labor and price competitiveness from the competitors. But day by day the economic and surrounding environment of ready-made garments industry become a human right challenge because of some deadly incidents. Sometimes it seems that different incidents are the common phenomenon in this sector. There are lots of factors that made the RMG sector challenging negatively. It is important to make the Bangladeshi apparel industry safe for the workers. The safe working environment will help to reduce the future uncertainties of different hazards. Different hazards are not only caused for life killing incidents but also the big issue of production damage and losses. These incidents impact negatively on sustainability and profitability. In this case, the rights for a safe working place are treated as international standard. Some causes are pushing negatively forward to unsafe working pace. But why these objects are making RMG sector so risky is a burning question. Fire hazard and building collapse are the two most influential factors behind this challenge. Fire in the RMG sector has become a widespread event in the recent years and causing large damage to lives and properties (Faruk 2016). The most responsive cause is the electric short circuit, and the least is overheating. On the other hand, the leading reason standing behind the building collapse is unplanned and unstructured building with the poor quality of materials. Sometimes supply chain responsibilities relates to building causes and different accidents.

\section{Objectives of the Research}

Some objects are pushing apparel industry negatively forward to unsafe working place. But why these causes are making RMG sector so risky is a burning question. This research will help to explore the effect and causes why Bangladeshi apparel industry in forwarding negatively. The specified objectives of this paper are listed below;

1. Identifying the deadly incidents in the history of apparel industry in Bangladesh

2. Illustrating the causes and effects of identified deadly incidents.

3. Specifying the precautionary actions for the stated 
causes of the identified deadly incidents.

\section{Review from Previous Research}

Exploring the working condition of Bangladeshi garments factory as overcrowded and difficult to move with a poor ventilation system. From the last ten years, almost 100 of workers have died due to the negligence of different problematic functions (Stanwick \& Stanwick 2015). The causes of fire in the garments factory as an electrical short circuit $(100 \%)$, boiler explosion $(44.29 \%)$, storage of flammable materials $(37.14 \%)$, transformer explosion (28.57\%), canteen kitchen $(24.17 \%)$, overheating $(8.57 \%)$ and others (21.43\%). Furthermore, almost $77.14 \%$ worker informed about fire by factory alarm, 20\% informed from management and $2.86 \%$ informed from the employee to leave the workplace. (Hossain 2016). There are many nongovernmental organisations (NGO) united under the common cause of reducing the disasters in the garment industry in Bangladesh and supporting the workers in their battle for increased wages. Most of the apparel companies have been accused of poor supply chain responsibilities (Velinova 2014). The causes for why the Bangladeshi garments industry so unsafe are that the rapid expansion of the industry led to the poor building structure quality and not obeying the government law. Sometimes not available of alternative employee and forcing female worker with a low payment (Clean Clothes Campaign 2012). Different types of loss occurred during any hazards; loss of affected infrastructure, loss of affected machinery, loss of materials, loss of production and loss of different issue, loss of Fire Fighting Units, and loss of Fire Extinguishers. Most of the losses occurred for the several fire incidents in the factory (Mizanuzzaman 2016). Twelve causes are responsible for different types of hazards. These are an overcrowded working condition, poor electrical connection, due date wages, not forming a labor union, improper training of management and worker, unavailability of safety tools, unavailability of a back door, narrow aisles, the poor relationship between the management and employee, disobeying building code and rumours (Kibria 2014). Fire Risk Index (FRI) in an adverse scale that means the higher FRI score lower the risks. In this model, the standard value of fire risks index is 5. Below five indicate that fire safety is not up to standard. Almost $100 \%$ factory considered as below standard in fire safety (Wadud, Huda \& Ahmed 2014). Different labour organisation demand to the government to explain their preventive measure for the victim in any incidents. Labor organisations raised the different legal issue against the company owner, building owner and government. In case of Tazreen Fashion fire incidents, labor unions demand emergency relief, medical cost, full and fair compensation to the victim and their family, ensure wages continuously even after not working, demanding permanent workers welfare funds. In these cases, buyers play some responsibility, such as; financial support for victims (BDT 100,000 per family in Tazreen Fashion fire incident) (Theuws
2013). Unfortunately, the safety issue regarding the different risks of ready-made garments industry in Bangladesh is very poor. Over the decade there were no auditing activities in the factories regarding safety issues from the responsible parties (Owners, Inspection Authority, and Government etc.). Health and safety issues are noticeably low in Bangladeshi apparel industry (Ahmed \& Hossain 2009). Different types of incidents are a common scenario of Bangladeshi garment factories. But the problem is that the precautionary activities after the hazard are sporadic. Even after the incident, nobody thinks for the sufferer except few organisations (Better Work 2013). An analysis has shown that almost 59\% factory need different types of safety assessments. These safety assessments include 51\% electrical safety, 30\% fire safety, and $19 \%$ structural safety (ILO / IFC 2016). Safety in the workplace is most important for all level of the apparel industry. In some cases when the fire occurred then all the factory gate was locked. In this case, it creates the more life risky situation. "Real fire safety means workers are free to report on dangers in their workplace and have the ability to negotiate better conditions; they have a voice that cannot be ignored. It also means that the large apparel buyers share their private knowledge of workplace hazards with workers and accept responsibility for their safety" (Deadly Secrets 2012).

\section{Methodology}

There are almost 4400 garments factories in Bangladesh. All the garments factory treated as population factors and the 69 garments factory treated as the sample. The samples are selected by the incidents as occurred in Bangladesh in last 22 years. Researchers have collected all the data from the secondary sources and followed different tools and equation to calculate the causes and effect of different types of incidents. Mainly, researchers prepared some equations for the calculation procedure. These equations are briefly stated below;

$$
\begin{aligned}
& \text { Building Collapse Incident (BCI) } \\
& =\frac{\text { Incident Occurred by Building Collapse }}{\text { Total Incident }} * 100
\end{aligned}
$$$$
\text { Fire Incident }(\mathrm{FI})=\frac{\text { Incident Occurred by Fire }}{\text { Total Incident }} * 100
$$

Death by Building Collapse (DBC)

$$
=\frac{\text { Number of Death by Building Collapse }}{\text { Total Number of Death }} * 100
$$

Death by Fire (DF) $=\frac{\text { Number of Death by Fire }}{\text { Total Number of Death }} * 100$

\section{Findings and Analysis}

\subsection{Major Deadly Incidents in RMG Industry}

In this research, the first objective is to identify the major 
incidents occurred in Bangladeshi garments sector. The last few year's data have shown in Table 1 . There are almost 1626 people died, and 4829 people or workers have injured seriously from the last 69 hazardous incidents in Bangladeshi garments sectors from 1990 to 2016. All of these incidents have direct and indirect influence over the profitability, productivity and growth of ready-made garments sector. The biggest hazardous incident was Rana Plaza collapse. Another most tragic hazard was Tazreen Fashions Ltd.'s fire incident. Besides these two, there were some deadly incidents in the history of Bangladeshi RMG sectors. These are briefly given below;

a. The Collapse of Rana Plaza: The tragic name 'Rana Plaza' was a nine-storeyed building situated in Savar, Dhaka. On 24 April 2013, at about 9 am, the biggest hazard in garments industry occurred in Bangladesh. Not only shocking for Bangladesh but also all over the world, it was a shocking incident for all. This building collapse occurred with a death roll about 1130 people lives and approximately 2400 people injured.

b. Tazreen Fashions Ltd: On 24 November 2012, Fire hazard occurred in Tazreen Fissions Ltd and fire broke out within the factory at around 7 p.m. while it was in operation. It is the biggest fire incident happened in Bangladesh causes death about 111-124 people and 200-300 worker injured.

c. Tampaco Foils Ltd: It was 6:15 am when the explosion took place about 100 workers were working in the morning shift. When a boiler blast At least 24 people have been killed and more than 50 people injured. The explosion caused a massive fire and led to the partial collapse of the three-storey factory building.

d. Chowdhury Knitwear and Garments Factory: The leading causes of fire in Chowdhury Knitwear and Garments Factory was a single spark from an electrical spot gun which was used to spray stain remover on soiled merchandise. At this time a worker tried most to fight the flames with an extinguisher, but unfortunately, it malfunctioned. The fire began on the $4^{\text {th }}$ floor of the factory.

e. Spectrum Factory, Dhaka, 2005: The building was not structurally sound and not appropriately designed. The causes of building collapse were that the building was erected on a flood-prone marshland which was not permitted by the authorities. In that accident, there were almost 64 workers killed and also injured of nearly 74 workers. f. Garib \& Garib Sweater Factory: On February 25th February 2010 almost 21 workers died when the factory caught fire for the second time in six months. The smoke could not get out because of the inadequate ventilation systems.

g. That's It Sportswear: Almost 24 workers died in a fiery inferno as the stairwell gate was locked and workers trapped on the ninth floor. Desperate to flee the heat and smoke, workers hurled themselves out of windows and died. Just four days after the fire, after the surviving workers went back to work, some plaster and cement came from the ceiling of the eighth floor and fell with a loud thud on the floor. A rumour that the roof was collapsing spread among the panicked workers. Almost 25 workers were injured in the ensuing stampede.

h. Standard Group: RMG workers set fire to the factory following a rumour over a death of their two workers in a clash with police. The news, in a moment, spread out to other floors of the ten-storey building. Workers also vandalised almost 20 vehicles parked inside the factory.

i. KTS Textile Factory: It was a fire incident in KTS Textile factory in 2006. Almost 63 workers were burned to death including nearly 150 workers injury. The problem was that they have only one exit way and the worker had to scramble on that time through a long narrow stairway to escape their life. At the same time, lots of workers were jumped from the windows. One remarkable fact that there was no fire safety equipment even ever been a fire drill.

j. Shifa Apparels and Omega Sweaters: A transformer close to the building, which stored six factories, burst and sparks flew in all directions. A pile of waste cloth from the factories caught fire, and the smoke reached the adjacent veranda. At the moment someone screamed, "Fire!" frightened workers hurried for the central staircase, but the narrow stairway was barely five feet wide. Unfortunately, the bottom gate was locked, and in the spot, seven young women were crushed to death in the resulting stampede. There were almost fifty other workers were injured in that incident.

k. Shan Knitting and Processing: Twenty-eight workers were "roasted alive", and more than 100 workers were injured. The fire broke out at 9:30 pm. All doors were locked. For that reason, workers could not get out within safety time.

Table 1. List of the Deadly Incidents 1990-2016.

\begin{tabular}{|c|c|c|c|c|c|}
\hline Name of The Factory & Location & Time & Cause & Death & Injury \\
\hline Saraka Garments, & Dhaka & 1990 & Fire & 32 & 25 \\
\hline Lusaka Garments & Dhaka & 1996 & Fire & 22 & 33 \\
\hline Nouvelle, Florence Fabrics, Modern Garments & Dhaka & 1997 & Fire & 5 & 50 \\
\hline Unknown factory & Dhaka & 1999 & Fire & 0 & 100 \\
\hline Chowdhury Knitwear and Garments & Dhaka & 2000 & Fire & 0 & 100 \\
\hline Europe Sweaters, AJAX Sweaters and Macro Sweater & & 2001 & Fire & 24 & 100 \\
\hline Shifa Apparels and Omega Sweaters, & Dhaka & 2004 & Fire & 7 & 50 \\
\hline Spectrum Factory & Dhaka & 2005 & Building Collapse & 64 & 74 \\
\hline
\end{tabular}




\begin{tabular}{|c|c|c|c|c|c|}
\hline Name of The Factory & Location & Time & Cause & Death & Injury \\
\hline KTS Textile Factory, & Chittagong & 2006 & Fire & 63 & 150 \\
\hline Multiple factories & Chittagong & 2006 & Fire & 0 & 100 \\
\hline Saiem Fashion & Gazipur & 2006 & Fire & 6 & 45 \\
\hline Garib \& Garib Sweater Factory & Gazipur & 2010 & Fire & 21 & 50 \\
\hline That's It Sportswear, Dhaka & Dhaka & 2010 & Fire & 29 & 25 \\
\hline Eurotex, & Dhaka & 2011 & Fire & 2 & 62 \\
\hline Tazreen Fashions Ltd & Dhaka & 2012 & Fire & 112 & 300 \\
\hline Swan Garments Ltd. & Uttara & 2012 & Fire & 1 & 0 \\
\hline Section Seven Garments & Chittagong & 2012 & Fire & 0 & 50 \\
\hline Crescent Leather Ltd. & Savar & 2012 & Fire & 0 & 16 \\
\hline Vision Apparels Ltd & Savar & 2012 & Fire & 0 & 100 \\
\hline BD Hechong & Gazipur & 2012 & Fire & 0 & 15 \\
\hline Pacific Blue Jeans & Savar & 2012 & Fire & 0 & 24 \\
\hline NRR Fashion Ltd & Narayanganj & 2012 & Fire & 0 & 5 \\
\hline AKH Stretch Garment & Beribadh & 2012 & Fire & 1 & 50 \\
\hline Active Composite Ltd & Ashulia & 2012 & Fire & 0 & 50 \\
\hline Nasa Basic Limited group & Ashulia & 2012 & Fire & 0 & 20 \\
\hline Cotton Club Limited & Gazipur & 2012 & Fire & 0 & 6 \\
\hline Bonded Fashion & Tongi & 2012 & Fire & 0 & 30 \\
\hline New Age Apparels Ltd. & Ashulia & 2012 & Fire & 0 & 5 \\
\hline Sagar Garments Ltd & Uttara & 2012 & Fire & 0 & 5 \\
\hline Ither Tex Ltd. & Savar & 2012 & Fire & 0 & 40 \\
\hline Ananta Knitwear Ltd. & Ashulia & 2012 & Fire & 0 & 10 \\
\hline Epic Garments Ltd & Narayanganj & 2012 & Fire & 0 & 15 \\
\hline Smart Export Garments & Dhaka & 2013 & Fire & 8 & 50 \\
\hline Rana Plaza & Dhaka & 2013 & Building Collapse & 1132 & 2400 \\
\hline Aswad Composite Mills Ltd. & Dhaka & 2013 & Fire & 7 & 50 \\
\hline Pacific Jeans 2000 & Chittagong & 2013 & Fire & 0 & 35 \\
\hline Abonti Colour Text, Unit 2 (Crony Group) & Narayanganj & 2013 & Fire & 0 & 50 \\
\hline Polycon Fashion & Gazipur & 2013 & Fire & 0 & 0 \\
\hline Smart Export Garment Ltd & Dhaka, & 2013 & Fire & 7 & 15 \\
\hline Abdullah Spinning Mill & Narayanganj & 2013 & Fire & 0 & 0 \\
\hline Envoy Garments Ltd. & Ashulia & 2013 & Fire & 0 & 100 \\
\hline A factory of Nisa Group & Comilla & 2013 & Fire & 1 & 2 \\
\hline Kang Book BD Limited & (CEPZ) & 2013 & Fire & 0 & 5 \\
\hline GM Garments Factory & Gazipur & 2013 & Fire & 0 & 3 \\
\hline Tung Hai Sweater Limited & Mirpur & 2013 & Fire & 7 & 0 \\
\hline Bandu Design Ltd. & Ashulia, & 2013 & Fire & 0 & 20 \\
\hline Uni Garment & Chittagong & 2013 & Fire & 0 & 14 \\
\hline Arba Textile Ltd & Ashulia & 2013 & Fire & 0 & 10 \\
\hline Nakano International Co. Ltd. & Ishwardi & 2013 & Fire & 0 & 7 \\
\hline JK Group Factory & Savar & 2013 & Fire & 0 & 10 \\
\hline Sicily Garments & Dhaka & 2013 & Fire & 0 & 3 \\
\hline Aswad Composite Mills & Gazipur & 2013 & Fire & 10 & 50 \\
\hline Riyad Dying & Gazipur & 2013 & Fire & 0 & 15 \\
\hline Aman Spinning Mills Ltd. & Ashulia & 2013 & Fire & 0 & 25 \\
\hline Mondol Group's garment factory & Ashulia & 2013 & Fire & 0 & 15 \\
\hline Green Leaf Apparel & Dhaka & 2014 & Fire & 0 & 1 \\
\hline Karnaphuli Knitting, Siddique Knitting Fashion and Park International Ltd. & Chittagong & 2014 & Fire & 2 & 0 \\
\hline ZA Sweater Factory & Dhaka & 2014 & Fire & 0 & 4 \\
\hline Syntax Industries Ltd. & Savar & 2014 & Fire & 0 & 2 \\
\hline S S Sweater Ltd. & Gazipur & 2014 & Fire & 0 & 10 \\
\hline Mayer Doha & Dhaka & 2014 & Fire & 1 & 3 \\
\hline Amina Exports Wear Limited & Ashulia & 2014 & Fire & 0 & 10 \\
\hline Mega Yarn Dyeing Mills Limited & Gazipur & 2014 & Boiler Burst & 1 & 4 \\
\hline Ishrak Spinning Mill & Gazipur & 2014 & Fire & 0 & 3 \\
\hline Kader Synthetic and Compact Spinning Mill & Gazipur & 2015 & Fire & 0 & 4 \\
\hline Supreme Jute and Knitex & Ashulia & 2015 & Fire & 0 & 4 \\
\hline Next Collection & Ashulia & 2015 & Fire & 0 & 30 \\
\hline Tampako & Tongi & 2016 & Boiler burst & 34 & 70 \\
\hline Total & & & & 1626 & 4829 \\
\hline
\end{tabular}

\subsection{Causes of the Deadly Incidents}

From the last 69 incidents of previous 22 years, 94.2\% incidents occurred by fire and only $3 \%$ incidents caused by building collapse and another $3 \%$ by others different incidents. The possibility of fire incident is more probable than the possibility of building collapse. Fire incident is the most common incident in the RMG sector of Bangladesh. Even 
most of the fire accident in RMG sector occurred by an electric short circuit in Bangladesh. Besides, the fire occurred by different causes, for instance, fire from boiler blast, fire from an electrical short circuit, fire from manual activities etc. On the other hand, building collapse is comparative less frequent than fire incident. The main causes of building collapse are poorly structured building and illegal construction. Almost 65 incidents out of 69 incidents were fire incident where only 2 or
3 from building collapse. The biggest fire incident was Tazreen fashion, standard group, Garib \& Garib, Erotex etc. And the two most influential building collapses were Rana Plaza and Spectrum garments limited. Here the different matter was that in Standard Group, a ten-storied building situated in Konabari, Gazipur, have set fire by the worker and finally the biggest garments in Gazipur were ruin in a day. The cause of this incident was labor unrest.

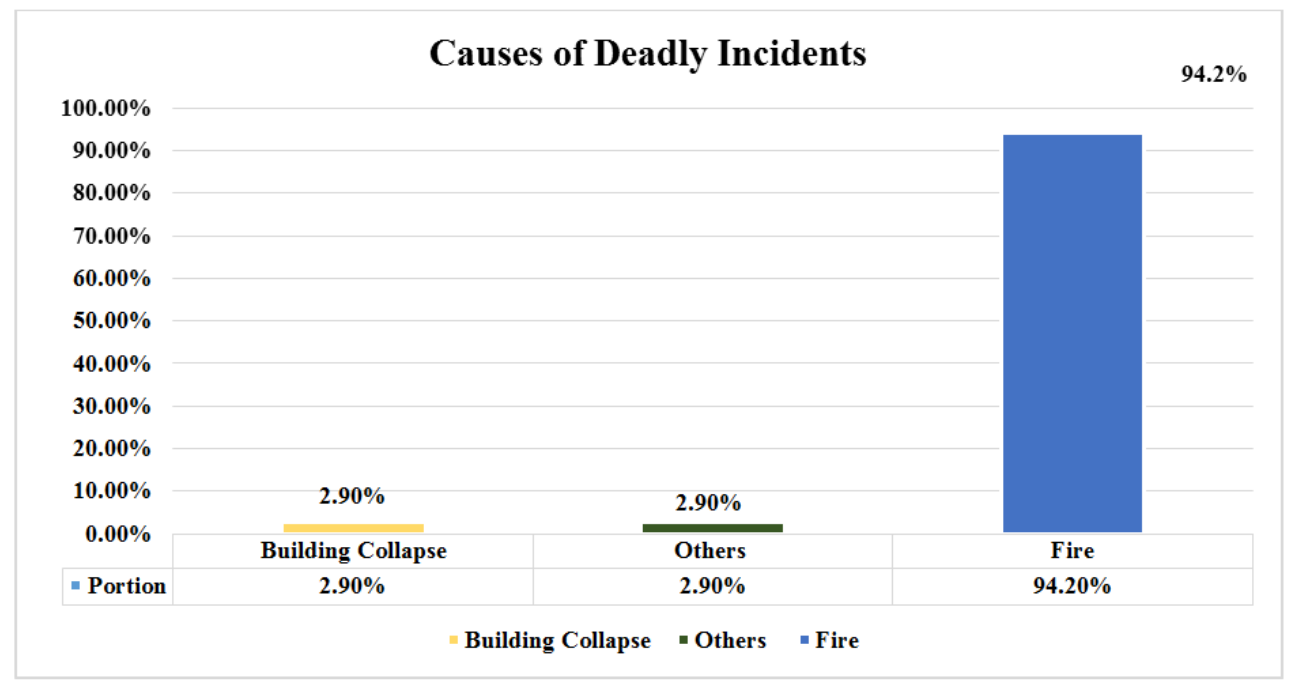

Figure 1. Causes of Deadly Incidents.

\subsection{Effect of the Deadly Incidents}

In the above Figure 1, it can be seen that the possibility of building collapse is only $3 \%$ and the possibility of fire incident is almost $94 \%$. Building collapse possibility is so less than the fire incident, but in cases of death and injury, the number of death is more than the number of death by fire. Here the percentage of death by building collapse is almost $74 \%$ where the rate of death by fire incidents is almost $24 \%$ [Figure 2]. Without this comparison, the number of the injured worker by building collapse is also more than the number of injured by fire. Almost $51.23 \%$ injured workers were from building collapse where $47.24 \%$ from fire is almost same to each other [Figure 3]. Fire is the most common incidents within the garments factory, and there are lots if fire incidents where there was no death but building collapse is not common but very serious than fire. In the 65 fire incidents from the total number of death is only 395 where only two building collapse incidents were the causes of almost 1196 workers death [Table 2]. That means building collapse incident is more and more serious than any other incidents within the garments factory. Besides the fire incidents and building collapse, there are some other causes for the deadly incident such as extreme labour unrest, stampede in an earthquake, stampede in fire alarming etc.

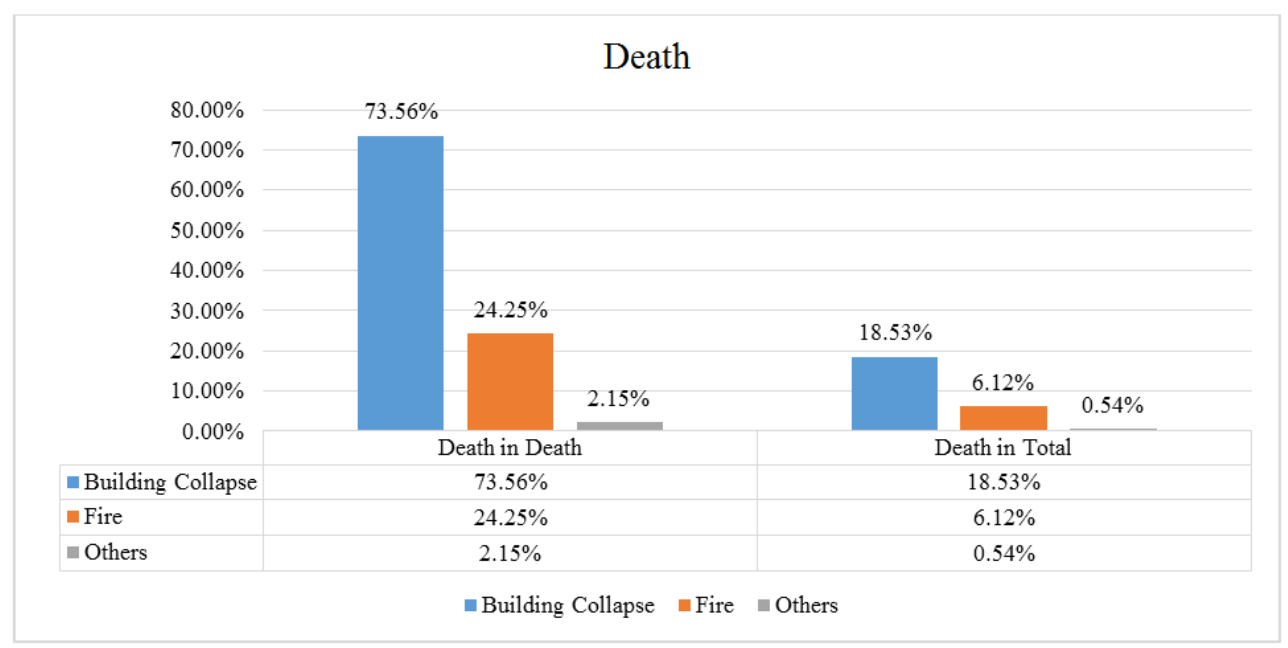

Figure 2. Effect of the Incidents (Death). 
Table 2. Compare between Death and Injury.

\begin{tabular}{|c|c|c|c|c|c|c|}
\hline Effect & Incidents & Death/Injured & $\%$ in Actual & $\%$ in Total & Number of Death/Injured & Total Death and Injured \\
\hline \multirow{4}{*}{ Death } & Building Collapse & 1196 & $73.56 \%$ & $18.53 \%$ & & \multirow{6}{*}{6455} \\
\hline & Fire & 395 & $24.25 \%$ & $6.12 \%$ & 1626 & \\
\hline & Others & 35 & $2.15 \%$ & $0.54 \%$ & & \\
\hline & Building Collapse & 2474 & $51.23 \%$ & $38.38 \%$ & \multirow{3}{*}{4829} & \\
\hline \multirow[t]{2}{*}{ Injured } & Fire & 2281 & $47.24 \%$ & $35.34 \%$ & & \\
\hline & Others & 74 & $1.53 \%$ & $1.17 \%$ & & \\
\hline
\end{tabular}

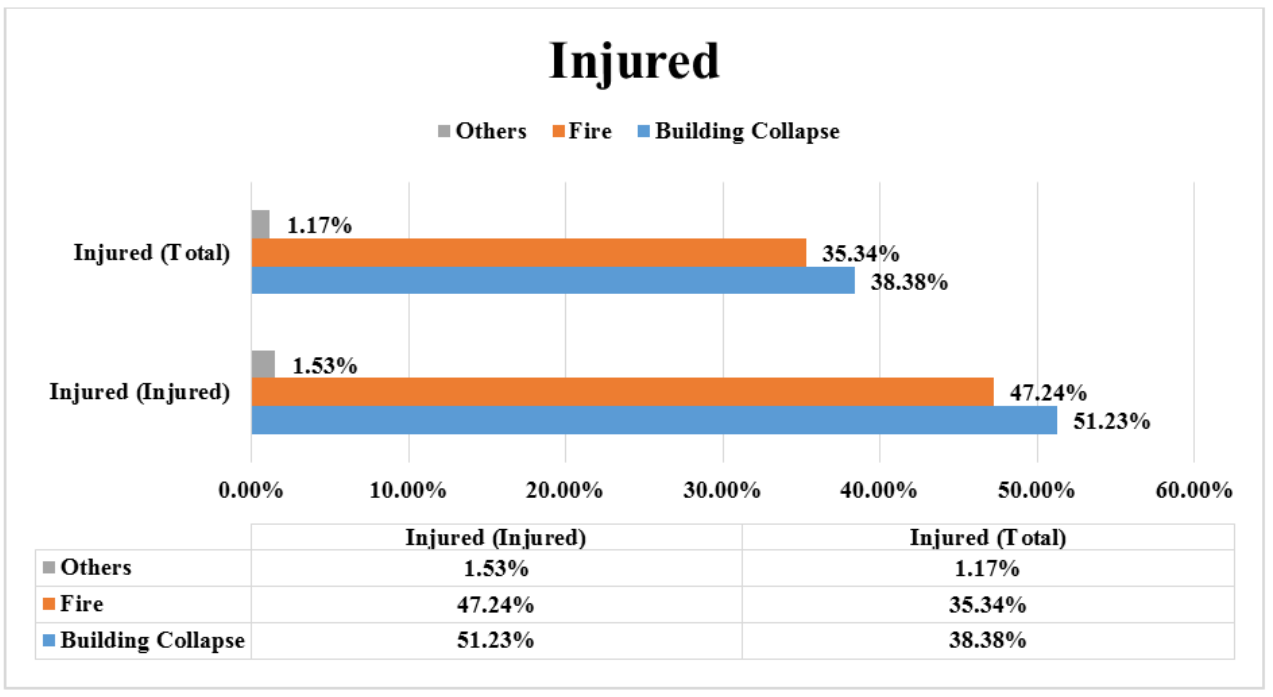

Figure 3. Effect of the Incidents (Injury).

\subsection{Precautionary Measures for Building Collapse and Fire Incidents}

It is crucial to take the necessary actions to ensure the safety of RMG sector in Bangladesh. All the responsible parties such as government, owners, stakeholders even employee also should take these measures in different ways.

Table 3. Precautionary actions for the Incidents.

\begin{tabular}{ll}
\hline Building Collapse & Fire Incidents \\
\hline Follow National Building Code & Follow the Fire Safety Act \\
Follow the building approval plan from RAJUK & Follow the Electricity Safety Act \\
Collect occupancy certificate before starting the production & Follow the Factory Act \\
Measure the wind speed before constructing the building & Proper training for management and employee \\
Audit focus on building safety & Special audit in electric sections \\
\hline
\end{tabular}

\section{Managerial Implications}

Without any doubt, Bangladeshi garments sector is treated as one of the riskiest working environment from the apparel producing country. Building collapse is deadlier than any other deadly incidents, but fire incident is the most likely incidents in Bangladeshi garments industry. Even it is deadly incident also. In this case, owner, management, government and employees are responsible for controlling building collapse risks by $71.43 \%, 0 \%, 35.71 \%, 0 \%$ respectively and in case of fire incident, owner, management, government and employees are responsible for controlling fire incident by $0 \%, 92.85 \%, 0 \%$ and $7.14 \%$ respectively (Hasan \& Mahmud 2017). So, the owner, management, government and employee should be aware of reducing the possibility by following the controlling techniques.

\section{Conclusion}

Therefore, a solution for permanent improvement of the working conditions for the garment workers in Bangladesh is to incorporate the development of a more comprehensive corporate social responsibility (CSR) philosophy related to the issues about global outsourcing. All the parties such as Bangladeshi government, brand and retailer, BGMEA/BKMEA and factory owner should play important responsibilities to prevent future tragedies. So, they should prepare to control all the activities in the garments sectors which need to be managed. Although the Fire Risk Index (FRI) indicates the fire safety standard is below the quality, there are enormous opportunities and scopes to develop the fire safety in the apparel industry of Bangladesh. Government should continue strict justification for the infrastructural standard of all the factory building. 


\section{References}

[1] Ahmed, J. U., \& Hossain, T. (2009). Industrial safety in the readymade garment sector: A developing country perspective. Sri Lankan Journal of Management, 14(1), 1-13.

[2] Better Work (2013). Fire and building safety in the readymade garment sector of Bangladesh. International Labour Organization / International Finance Corporation.

[3] Björn Claeson (2012). Deadly Secrets. International Labor Rights Forum.

[4] Bolle, M. J. (2014). Bangladesh apparel factory collapse: Background in brief. Congressional Research Service Report, 7-5700.

[5] Campaign, C. C. (2012). Hazardous workplaces: Making the Bangladesh Garment industry safe.

[6] D'Ambrogio, E. (2014). Workers' Conditions in the Textile and Clothing Sector: Just an Asian Affair? Issues at Stake after the Rana Plaza Tragedy. European Parliamentary Research Service.

[7] Hasan, M., \& Mahmud, A. (2017). Risks Management of Ready-Made Garments Industry in Bangladesh. International Research Journal of Business Studies, 10(1).

[8] Hideki, S. (2015). Preventing Factory Fires through Contracts: Case study of Garment Factories in Bangladesh. International Journal of Business and Social Research, 5(4), 09-13.

[9] Hossain, M. F. Fire Hazard in Readymade Garment Factories and Its Impacts on Workers in Dhaka Metropolitan Area, Bangladesh.

[10] Kibria, M. F. Identifying and Eliminating Industrial Hazards in RMG Industries: A Case Study. International Journal of Scientific Research Engineering \& Technology (IJSRET), ISSN 2278 - 0882. Volume 3 Issue 1, April 2014.

[11] Mizanuzzaman, M. (2016). Loss and Damage Assessment in the Context of Fire Hazards: A Study on Selected Garment Factories in Bangladesh. International Journal of Finance and Banking Research, 2(2), 24.

[12] Rahman, S M., Arif, M. M. H., Islam, M. S. (2016), "IFTAR Business Process and Strategies: A Study of IFTAR Shop in Rangpur City-Corporation", Science Journal of Business and Management 4(4), 127-131.

[13] Rahman, S M., Islam, M. S., Arif, M. M. H. (2016). Investment Approval Process of ISLAMIC Banking - An Identical Investment Approval Process Model: A Case Study on Some Selected Islamic Banks in Bangladesh. International Journal of Business and Economics Research, 5(5), 155.

[14] Stanwick, P., \& Stanwick, S. (2015). The garment industry in Bangladesh: A human rights challenge. Journal of Business \& Economic Policy, 2(4), 40-44.

[15] Theuws, M. (2013). Fatal Fashion: Analysis of Recent Factory Fires in Pakistan and Bangladesh: a Call to Protect and Respect Garment Workers' Lives. SOMO, Centre for Research on Multinational Corporations.

[16] Velinova, R. (2014). The Case of Rana Plaza: A precedent or the severe reality? The Beagle: a Journal of Student Research and Enterprise, 2(2).

[17] Wadud, Z., Huda, F. Y., \& Ahmed, N. U. (2014). Assessment of fire risk in the readymade garment industry in Dhaka, Bangladesh. Fire Technology, 50(5), 1127-1145.

[18] (2016). Remediation Financing in Bangladesh's Ready-Made Garment Sector: An Overview. International Labor Organization / International Finance Corporation. 